\title{
PEMBANGUNAN MASYARAKAT SEBAGAI KONSEP DAKWAH DAN PEMBANGUNAN MADINAH SEBAGAI CONTOH COMMUNITY DEVELOPMENT
}

\begin{tabular}{|c|c|c|}
\hline \multicolumn{3}{|c|}{ P-ISSN: 2085-4536 | E-ISSN: 2721-7183 } \\
\hline \multicolumn{3}{|c|}{ Link: https://jurnal-stidnatsir.ac.id/index.php/dakwah/article/view/46 } \\
\hline \multicolumn{3}{|c|}{ DOI : $\underline{\text { https://doi.org/10.38214/jurnaldawahstidnatsir.v2i01.46 }}$} \\
\hline Dikirim: 25-03-2019 & Direview: 05-04-2019 & Diterbitkan: 17-04-2019 \\
\hline \multicolumn{3}{|c|}{$\begin{array}{c}\text { SYA'RONI TOHIR } \\
\text { STID Mohammad Natsir - Indonesia } \\
\text { syaroni@stidnatsir.ac.id }\end{array}$} \\
\hline
\end{tabular}

\begin{abstract}
ABSTRAK
Tujuan Penelitian: Penelitian ini bertujuan untuk mengetahui konsep pembangunan masyarakat dan pembangunan Madinah sebagai contoh community development. Metode Penelitian: Kualitatif. Hasil Penelitian: Konsep pengembangan masyarakat menurut Islam lebih holistik dari pada konsep pengembangan masyarakat secara umum. Dalam konsep pengembangan masyarakat menurut Islam tidak hanya dibangun hubungannya dengan sesama manusia (hubungan vertikal) tetapi dibangun juga hubungannya dengan sang pencipta Allah Yang Maha Kuasa (horisontal). Konsep Pengembangan Masyarakat adalah bagian dari Konsep Da'wah. Oleh kerena itu hendaknya para pelaku pengembangan masyarakat dari kalangan umum menggunakan konsep Da'wah sebagai konsep pengembangan masyarakat. Dan yang lebih terpenting lagi sudah seharusnya bagi para da'i, melakukan pengembangan masyarakat sebagai implementasi konsep da'wah.
\end{abstract}

Kata kunci : pengembangan masyarakat, konsep dan dakwah.

\section{PENDAHULUAN}

Pengembangan masyarakat (community development) merupakan suatu proses menuju perubahan masyarakat ke arah yang lebih baik pada semua aspek kehidupan masyarakat baik yang bersifat lahiriyyah maupun 
bâthiniyyah, jasmaniyyah dan rûhaniyyah, moril maupun materil. Dan pengembangan masyarakat harus dilakukan secara bersama-sama antara organisasi pemerintah (OP), organisasi masyarakat (Ormas) atau lembaga swadaya masyarakat (LSM), tokoh masyarakat dan masyarakat itu sendiri (semua steak holder). Semuanya secara bersama-sama bahu mebahu berusaha membuat suatu perubahan di masyarakat ke arah yang lebih baik. Dalam prakteknya tentu ada subyek (pelaku pengembangan) masyarakat selaku obyek (yang dikembangkan) dan ada yang yang sekaligus mereka subyek pengembangan sekaligus mereka juga sebagai obyek pengembanagan Semuanya harus berjalan seiring, sama-sama memiliki keinginan kuat untuk berubah menjadi lebih baik dan lebih maju dengan semangat yang sama.

Semua pelaku perubahan itu secara bersama-sama melakukan proses upaya perubahan di semua bidang dan masing pelaku perubahan melakukan proses upaya perubahan pada bidangnya masing-masing. Ada yang melakukan perubahan pada bidang pendidikan secara umum, ada yang melakukan perubahan di bidang mental spiritual, ada yang melakukan upaya pengembangan ekonomi, pengembangan kesehatan, seni budaya dan sebagainya.

Selanjutnya da'wah. Da'wah adalah upaya mengajak manusia kepada kebaikan holistic. Melakukan upaya perubahan kehidupan manusia ke arah yang lebih baik pada semua bidang dengan didasari keimanan kepada Tuhan Yang Maha Esa. Tidak sekedar pola kehidupannya saja, tapi nowlage dan etitutnya, budaya dan tingkah-lakunya, kemajuan teknologinya. Semuanya harus berkembang di atas dasar-dasar keimanan kepada Allah subabânabu wa ta'âla, para malâikat, kitab-kitab, rasûl-rasûl, hari akbîr dan kepada takdîr. Pengembangan masyarakat dengan konsep da'wah yang berdasarkan keimanan ini sangat penting, sebab masyarakat yang maju dan berkembang peradabannya yang tidak berdasarkan keimanan dan ketaqwaan kepada Allah SWT, maka kehidupannya akan rapuh. Contoh; tingginya angka bunuh diri di negara maju (menurut padigma bumi) disebabkan karena masyarakat itu perkembangannya tidak didasari dengan keimanan dan ketawaan kepada Tuhan Yang Maha Esa. Sehingga mudah putus asa. Sebaliknya pengmbangan masyarakat dengan konsep da'wah yang berdasarkan keimanan dan ketaqwaan kepada Tuhan Yang Maha Esa, akan menciptakan tatanan masyarakat yang indah, kuat mental dan tidak mudah putus asa. 
Dari uraian di atas konsep da'wah menjadi sangat penting untuk dijadikan sebagai konsep penegembangan masyarakat. Apa yang sudah berjalan di negara "maju" sebagai pola pengembangan masyarakat adalah sudah baik namun masih ada yang kurang. Yaitu seperti bunga hiasan di taman pengantin, ia indah tapi tak berakar, ia akan cepat layu dan terbuang sia-sia. Tetapi bunga di taman sesungguhnya tidak sekedar indah, tapi ia berakar kuat tak mudah layu, memproduksi putik dan dihisap kumbang penghasil madu. Ooh sungguh indah konsep da'wah jika dijadikan sebagai konsep pengembangan masyarakat di seluruh dunia.

Pengembangan Masyarakat. Dalam KBBI. Pertama, pengembangan adalah proses atau cara mengembangkan ${ }^{1}$. Kedua, masyarakat ialah sejumlah manusia dalam arti yang seluas-luasnya dan terikat oleh suatu kebudayaan yang mereka

Menurut Fredian Tonny Nasdian pengembangan masyarakat (community development) konsep dasar yang menggaris bawahi sejumlah istiah yang telah digunakan sejak lama, seperti community resource development (Pengembangan Sumber daya masyarakat), rural areas development (Pengembangan Area Pedesaan), community economic development (Pengembangan Ekonomi Masyarakat), rural refitalisation (Revitaliasasi Pedesaan), dan community based development (Pengembangan Berdasarkan Masyarakat). Community development menggabungkan makna yang penting dari dua konsep : community bermakna kualitas hubungan social dan development bermakna perubahan kea rah kemajuan yang terencana dan bersifat gradual. Makna ini penting untuk untuk arti pengembangan masyarakat yang sesungguhnya (Blackburn, 1989). ${ }^{2}$

Menurut M. Djauzi Moedzakir, pengembangan masyarkat adalah suatu lapangan akademis dan terapan. Yang menjadi tujuan pokoknya

${ }^{1} \mathrm{KBBI}$ online. Berikut petikan secara lengkap ; Pengembangan/ pe.ngem.bang.an / $\mathrm{n}$ proses, cara, perbuatan mengembangkan : pemerintah selalu berusaha dalam $\sim$ pembangunan secara bertahap dan teratur yang menjurus ke sasaran yang dikehendaki; bahasa upaya meningkatkan mutu bahasa agar dapat dipakai untuk berbagai keperluan dalam kehidupan masyarakat modern; masyarakat proses kegiatan bersama yang dilakukan oleh penghuni suatu daerah untuk memenuhi kebutuhannya.

2 Fredian Tonny Nasdian, Pengembangan Masyarakat, Yayasan Pustaka Obor Indonesia, (Jakarta : 2014), h.29. 
adalah pengembangan manusianya. Pertanyaan "bow" atau "bagaimana" seseorang bergerak di lapangan masyarakat, adalah merupakan suatu tinjauan praktis. Sedangkan pertanyaan "why" atau "mengapa" seseorang bergerak dengan sesuatu cara tertentu adalah merupakan suatu tinjauan segi teoritis beserta segala prinsip-prinsipnya. ${ }^{3}$

Pemerintah kolonial Inggris memperkenalkan mengadopsi definisi pengembangan masyarakat yang lebih singkat pada tahun 1948. Hal ini dilakukan ketika mereka memperkenalkan konsep pengembangan masyarakat di Malaysia. :

Pengembangan masyarakat adalah gerakan yang dirangcang untuk meningkatkan kehidupan selurub komunitas dengan partisipasi aktif dan atas prakarsa komunitas.

PBB (1960) mendefinisikan pengembangan masyarakat (community development) sebagai berikut :

Community development is processes by which the effort of the people themselves are united whit those of governmental outhorities to inprove the economic, social and cultural conditions of communities, to integrate the communities into the life of the natio, and to enhance the contribute fully to national progress.

Pengembangan masyarakat adalah proses di mana upaya rakyat bersatu dengan orang-orang yang memiliki kebijakan pemerintah untuk. mendorong kondisi ekonomi, sosial dan budaya masyarakat, mengintegrasikan masyarakat ke dalam kehidupan nasional, dan untuk meningkatkean kontribusi sepenubnya kepada kemajuan nasional.

Istilah lain dari pengembangan masyarakat yang memiliki ma'na dan tujuan yang sama adalah pemberdayaan masyarakat. Pemberdayaan masyarakat pada dasarnya merupakan strategi perubahan sosial secara terencana yang ditujukan untuk mengatasi masalah atau memenuhi

${ }^{3}$ M. Djauzi Moedzakir, Teiri dan Praktek Pengembangan Masyarakat, (Surabaya : 1986), Usaha Nasional, h. 9. 
kebutuhan masyarakat. Dalam proses pemberdayaan, masyarakat mendapatkan pembelajaran agar dapat secara mandiri melakukan upayaupaya perbaikan kualitas kehidupannya. Dengan demikian, proses tersebut harus dilaksanakan dengan adanya keterlibatan penuh masyarakat itu sendiri secara bertahap, terus-menerus, dan berkelanjutan.

Payne (Nasdian, 2014, p.89) menyatakan bahwa pemberdayaan (empowerment) merupakan suatu proses yang ditujukan untuk membantu masyarakat memperoleh daya (kuasa) untuk mengambil keputusan dan menentukan tindakan yang akan ia lakukan, termasuk mengurangi efek hambatan pribadi dan sosial dalam melakukan tindakan.

Suatu pemberdayaan tentunya memiliki tujuan yang akan dicapai. Ife \& Tesoriero (2008, p.662) menjelaskan bahwa "pemberdayaan bertujuan meningkatkan keberdayaan dari mereka yang dirugikan (the disadvantaged)".4 Peran pemberdayaan masyarakat terutama di pedesaan untuk menggerakkan, mengubah cara pandang, dan mewujudkan tujuan kegiatan secara berkelompok akan lebih mudah. Masyarakat didorong dari keinginannya sendiri bukan hanya sebagai persyaratan proyek. Penguatan kelembagaan yang ada atau pembentukan baru, mulai dari mendisplinkankan pertemuan rutin di dalam dan antar kelompok tani, dan saling berkoordinasi antar kelompok tani, mengaktifkan koperasi kelompok tani, dan mendorong personal yang mampu memotivasi masyarakat petani lainnya.

Suatu masyarakat yang memiliki keterbatasan pengetahuan, memahami permasalahan, cara memecahkan masalah dan alternatif pilihan untuk menyelesaikan masalah, sehingga memerlukan pendamping seperti penyuluh, kini perannya dibantu oleh hadirnya pendamping lokal desa dan pendamping desa.

\footnotetext{
${ }^{4}$ Wildan Saugi, Sumarno, SMPIT As-Salaam Fakfak Papua Barat, Universitas Negeri Yogyakarta, wildan_saugi@yahoo.com, sumarno_unj@yahoo.uk, PEMBERDAYAAN PEREMPUAN MELALUI PELATIHAN PENGOLAHAN BAHAN PANGAN LOKAL. Jurnal Pendidikan dan Pemberdayaan Masyarakat Volume 2 Nomor 2, November 2015, (226 - 238) Available online at JPPM Website: http://journal.uny.ac.id/index.php/jppm Copyright (C) 2015, JPPM, Print ISSN: $2355-$ 1615, Online ISSN: 2477-2992 Wildan Saugi, Sumarno, SMPIT As-Salaam Fakfak Papua Barat, Universitas Negeri Yogyakarta, wildan_saugi@yahoo.com, sumarno_unj@yahoo.uk
} 
Maka konsep penyelesaiannya adalah edukasi, masyarakat diberikan penyuluhan dan pendampingan. Sampai masyarakat memahami persoalan di desanya dan mulai berfikir mencari terobosan yang harus dilakukan. Dari sini kita memahami bahwa memberikan pemahaman kepada masyarakat agar mau merubah keadaan menjadi lebih baik, mau melakukan inovasi dan berontak melawan kemiskinan dan keterbelakangan serta keterpurukan adalah muthlak dilakukan agar ketika ada pihak luar yang ingin membantu melakukan perubahan, maka masyarakat akan merasa antusias dan mau melakukannya bersama-sama.

\section{Langkah-langkah Pengembangan Masyarakat}

Pelaksanaan pengembangan masyarakat dapat dilakukan melalui penetapan sebuah program atau proyek pembangunan. Secara garis besar, perencanannya dapat dilakukan dengan mengikuti 6 langkah perencanaan, yaitu:

Langkah pertama: Penelitian untuk mencari jawaban masalah apa yang sedang dihadapi masyarakat yang paling urgen untuk selanjutnya menentukan program sebagai solusi yang tepat bagi pengembangan masyarakat. Program dibuat berdasarkan masalah atau kebutuhan masyarakat setempat. Sasaran pengembangan biasanya meliputi aspek pendidikan, ekonomi, kesehatan, seni budaya dan lain-lain. Perumusan program dilakukan dengan menggunakan penelitian (survey, wawancara, observasi), diskusi kelompok, rapat desa, dan sebagainya.

Langkah kedua : Edukasi masyarakat. Setelah masalah dan program solusi telah di temukan atau dapat diidentifikasi dan disepakati sebagai prioritas yang perlu segera ditangani, maka mulailah masyarakatnya di edukasi atau diberikan penyuluhan.

Langkah ketiga: Merumuskan target capaian program. Agar program dapat dilaksanakan dengan baik dan keberhasilannya dapat diukur, perlu dirumuskan target dan tujuan dari program yang telah ditetapkan. Tujuan yang baik memiliki karakteristik jelas dan spesifik sehingga tercermin bagaimana cara mencapai tujuan tersebut sesuai dengan dana, waktu dan tenaga yang tersedia. 
Langkah keempat : penentuan kelompok sasaran. Kelompok sasaran adalah sejumlah orang yang akan ditingkatkan kualitas hidupnya melalui program yang telah ditetapkan.

Langkah kelima: Identifikasi sumber dan tenaga pelaksana. Sumber adalah segala sesuatu yang dapat digunakan untuk menunjang program kegiatan, termasuk didalamnya adalah sarana, sumber dana, dan sumber daya manusia.

Langkah keenam : Penentuan strategi dan jadwal kegiatan. Strategi adalah cara atau metoda yang dapat digunakan dalam melaksanakan program kegiatan.

Ke tujuh : Monitoring dan evaluasi. Monitoring dan evaluasi dilakukan untuk memantau proses dan hasil pelaksanaan program.

\section{Konsep Dakwah}

Konsep adalah rancangan, ide, atau gambaran dari sebuah objek, yang diungkapkan untuk memberikan pemahaman kepada orang lain. ${ }^{5}$

Sedangkan kata "da'wah" dalam al-Qur'an dari berbagai isytiqâq mempunyai arti antara lain: do'a ${ }^{6}$, mengajak $^{7}$, mendakwa $^{8}$, mengadu , memanggil ${ }^{10}$, meminta ${ }^{11}$, mengundang ${ }^{12}$ dan anak angkat ${ }^{13}$.

Kemudian kata "da'wah" menurut AW Munawwir mempunyai beberapa arti antara lain:

${ }^{5}$ Konsep memiliki 3 makna : 1 rancangan atau buram surat dan sebagainya; 2 ide atau pengertian yang diabstrakkan dari peristiwa konkret: satu istilah dapat mengandung dua -- yang berbeda; 3 Ling gambaran mental dari objek, proses, atau apa pun yang ada di luar bahasa, yang digunakan oleh akal budi untuk memahami hal-hal lain. Mengonsep/me·ngon·sep/ v membuat konsep (rancangan);

\footnotetext{
${ }^{6}$ QS Ali Imran : 38

QS Yusuf : 108

${ }^{8}$ QS Maryam : 91

9 QS Al-Qomar : 10

${ }^{10}$ QS Ar-Ruum : 25

${ }^{11}$ QS Shad : 51

12 QS Al-Qashash : 25

13 QS Al-Ahzab : 4
} 
a) فلان دعاه بالشيء Meminta/ mengundang, misalnya dikatakan Si fulan telah meminta kehadirannya di suatu tempat.

b) حثه على قصده : حendorong/ memotifasi, mislanya dikatakan fulan telah memotifasi dia kepada tujuannya.

c) فلان دعاه إلى الصلاة، فلان دعاه إلى القتال، فلان دعاه إلى الإسلام Mengajak, misalnya dikatakan: Si fulan mengajak dia shalat, si fulan mengajak dia berperang, si fulan mengajak dia masuk Islam. ${ }^{14}$

Dalam kamus besar bahasa Indonesia kata "da'wah" sebagai n.1. (Dialek Melayu) diartikan penyiaran, propaganda; n.2. (bahasa daerah) berarti penyiaran agama dan pengembangannya dikalangan masyarakat, seruan untuk memeluk, mempelajari dan mengamalkan ajaran agama. ${ }^{15}$

Berbeda dengan kata "Da'wah" yang mempunyai arti n.1. (dialek Melayu) tuduhan; n.2. (bahasa daerah) pengaduan atau tuntutan yang diajukan pada hakim; n.3. (bahasa asing) tuntutan atau gugatan yang diajukan oleh seseorang terhadap orang lain karena haknya telah dilanggar, dirugikan. Dan kata "berdakwah" berarti bersidang atau diperkara .

Merujuk kepada pengertian yang ada dalam KBBI dan kamus alMunawwir, kata da'wah dapat diartikan suatu upaya untuk mengajak manuasi ke jalan Allah atau menyiarkan dan mengembangkan agama islam.

Jadi konsep da'wah ialah suatu rancangan upaya untuk mengajak manusia (masyarakat) ke jalan Allah (kebaikan) atau menyiarkan dan mengembangkan agama Islam dan kehidupan masyarakat.

دعوة الناس إلى الحير / دعوة الناس إلى سبيل الله / دعوة الناس إلى دين الإسلام ، دعوة الناس إلى ما

Tahapan Konsep Dakwah
a. Tabligh (التبليغ) = menyampaikan kebenaran
b. Ta'lim (التعليم) = mengajar / mendidik

\footnotetext{
${ }^{14}$ AW.Munawwir, Kamus Arab-Indonesia, (Suarabaya:Pustaka Progresif, 1997), cet. Ke-14.h.406.

15 Tim penyusunan kamus, Pusat Pedanmbinaan dan Pengembangan Bahasa, Kamus Besar Bahasa Indonesia (Jakarta: Balai Pustaka, 1994) ed. 2, cet. 3, h. 205.
} 


$$
\begin{aligned}
& \text { c. Tanzhim (النظيم) = mengorganisir } \\
& \text { d. Tanfidz (الننفيذ) = penugasan / melaksanakan program }
\end{aligned}
$$

Tujuan-tujuan Da'wah (أهداف الدعوة)

: أهداف الدعوة هي التغيير (tujuan-tujuan da'wah adalab melakukan perubahan). Seorang da'i adalah agen perubahan di masyarakat. Dimana ada seorang da'i maka di situ harus ada perubahan ke arah perbaikan pada masyarakat. Adapun ruang lingkup jangkauan perubahan yang terjadi di masyarakat tergantung pada kapabilitas dan keseriusan seseorang dalam berda'wah. Oleh karena itu ada istilah أستاذ صغير في مسجد صغير (ustadz, kecil di masjid kecil) sebaliknya أستاذ كبير في مسجد كبير (ustadz, besar di masjid besar). Bahkan ada seorang da'i yang berpredikat أستاذية العالم (da'i internasional). Dan juga tergantung bidangnya masing-masing. Seorang da'i yang bidangnya ceramah, maka dia berda'wah dengan ceramah, yang bidangnya mengajar, maka da'wahnya dengan mengajar, yang bidangnya berorganisasi dan berpolitik, maka ia berda'wah dengan politik, yang bidangnya fiqhul ahkam, maka ia berda'wah dengan membuat istinbath (keputusan) hukum. Dan lain sebagainya. Yang kesemuanya mempunyai tujuan $\mathrm{mmm}$ (untuk memenangkan agama Islam). Agar manusia semua menjalankan syari'at Islam, agama Allah, dinul haqq. Adapun perubahan-perubahan da'wah yang ingin dicapai tentunya tergantung mad'u yang dihadapinya. Sebagai contoh; seorang da'i seperti Dzakit Naik yang bidang da'wahnya menda'wahi orangorang non muslim, maka terget da'wahnya dia adalah merubah seorang kafir menjadi muslim. Setelah menjadi muslim, maka itu menjadi tugasbagi da'i yang lainnya untuk membimbing mu'allaf (orang yang baru masuk Islam) yang belum faham syari'at Islam menjadi orang yang memahami syari'at Islam. Demikian seterusnya. Adapun tujuan-tujuan da'wah itu sangat beragam seperti :

$$
\begin{array}{r}
\text { - } \\
\text { - } \\
\text { - }
\end{array}
$$

(menyembah Khalik 
- من الضلالة إلى الهدى (dari sesat kepada petunjuk)

- من - من الجاهل إلى العالم (dari bodoh kepada pandai)

- من الرجل إلى الرجال (dari orang biasa menjadi tokoh besar) -

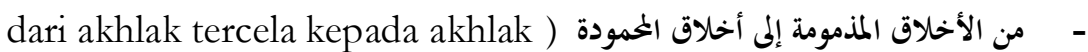

(terpuji

من الثقافة الجاهلية إلى الثقافة الإسلامية ( dari budaya jahiliyyah kepada

(budaya islami

من الخاربة إلى المسالمة (dari suka perang kepada suka perdamaian)

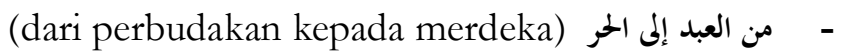

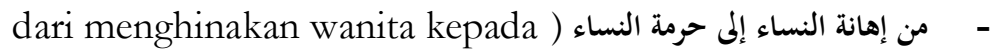

(memuliakan wanita

- - من الزنا إلى النكاح (dari perzinahan kepada pernikah)

- من الربا إلى الالبيع (dari riba kepada jual beli) -

- من أكل الحرمات إلى أكل الحلال (dari makan yang haram kepada yang halal)

- من الشر إلى الحير (dari keburukan kepada kebaikan)

- من - من الفراغ إلى العمل (dari pengangguran kepada bekerja)

- - من الكسلاء إلى الناشطات (dari pemalas kepada pegiat)

- من المساكين إلى الأغنياء (dari miskin kepada kaya) -

- من الضعف إلى القدرة (dari lemah kepada berdaya) -

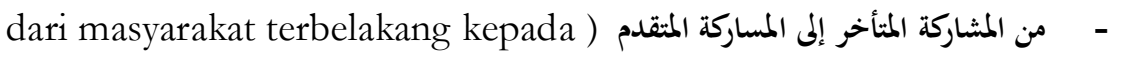

(masyarakat maju

- - من المستحق إلى المزكي (dari penerima zakat kepada pemberi zakat)

- - من غلبة الدين إلى براءة الدين (daari terlilit hutang kepada bebas hutang)

- مغير ذالك (dan lain sebagainya) -

Untuk mengimplementikan semua tujuan-tujuan da'wah itu, maka diperlukan da'wah secara holistik. Maksunya ialah da'wah bil lisan dan bil 
Hal dan dengan totalitas waktu, tenaga, fi kiran, jiwa raga dan semua potensi yang dimiliki da'i.

\section{HASIL DAN DISKUSI}

Dalam pembahasan ini penulis berusaha meneliti bagaimana rasulullah shallallahu alaibi wa sallam sebagai da'I dan pemimpin wilayah Madinah berusaha membuat pemetaan masalah yang dihadapi di Madinah ketika beliau berada di Madinah dan membuat langkah-langkah kebijakan terobosan untuk mengatasi masalah yang ada kemudian membangun dan mengembangkan kota Madinah sehingga menjadi yang berpredikat baldatun thayyibatun wa rabbun ghafur (kota atau negri yang baik dan diampuni oleh rabbul 'alamin)

\section{Makkna Yatsrib}

Menurut Ibnul Manzhur يثرب dari kata ثرب م الثرب artinya

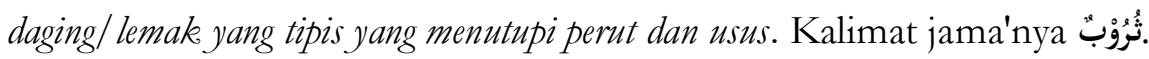

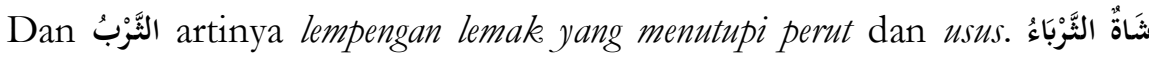

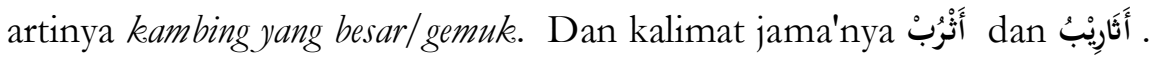
Dalam Firman Allah SWT : لاتثريب عليكم اليوم. Menurut Tsa'lab ma'nanya adalah : Hari ini janganlah kalian mempermalukkan diri kalian. Hari ini anganlah diingat-ingat (perbuatan dosa) kaian. Hari ini janganlah kalian menyalabkan diri kalian. ${ }^{16}$

Dalam Hadits Rasulullah SAW :

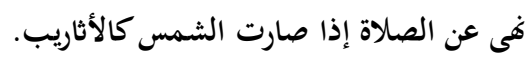

Rasulullah $S A W$ melarang shalat apabila matahari seperti kambing yang daging perutnya besar.

16 Muhammad Bin Jarir, Bin Yazid Bin Katsir, Bin Ghalib Al-'Amily, Abu Jafar At-Thabary (310 H), Jami' al-Bayan Fi Tafsir al-Qur'an, Muasasah Ar-Risalah : 2000 M/ $1420 \mathrm{H}$. 


\section{إن المنافق يؤخر العصر حتى إذا صارت الشمس كالأثاريب صلاها.}

Sesunggubnya orang munafik menakhirkan shalat ashar hingga matahari seperti kambing yang daging perutnya besar.

Kata تعيير dan أنثيب dan استقصاء في اللوم Seprti (mencela, memarahi, menghina). الثارب الموبخ (orang yang mencela, menegur, mendamprat). ${ }^{17}$

Menurut Ibnu 'Abbas : لاتثريب عليكم اليوم أي لا أعيركم بعد اليوم (Aku tidak akan mempermalukan kalian sesudah hari ini).

Menurut Abdullah Bin Muslim Bin Qutaibah Ad-Dainuri ( 276) : Asal ma'na التّريب yaitu الإفساد (merusak). Contoh kalimat :

ثرّب علينا، إذا أفسد (merusake kami). Dan di dalam hadits :

(إذا زنت أمة أحدكم: فليجلدها الحدّ، ولا يثرّب (Apabila Budak wanita kalian berzina maka jilidlah sesuai bukuamannya dan jangan dikurangi). ${ }^{18}$

Menurut Mujahid (104 H) : لاتثريب عليكم اليوم أي لا أباءٌ (hari ini aku tidak mau kalian mencela diri kalian). ${ }^{19}$

Menurut Ahmad Warson Munawwir يُربَ mempunyai arti أَتَرَب و

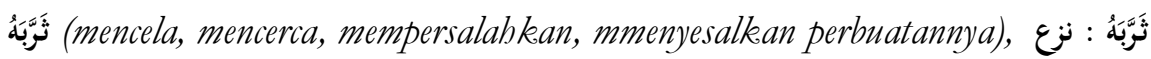

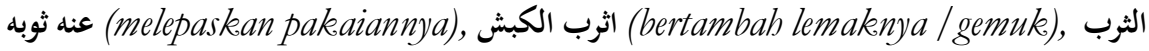

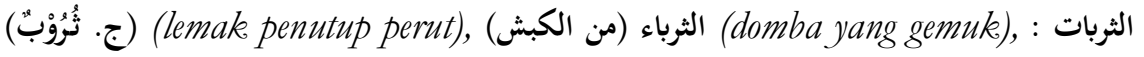
الأصابع (jari-jari), المثرب : قليل العطاء (yang sedikit pemberiannya).

17 Jamaluddin Muhammad Bin Mukrim Ibnu al-Manzhur Al-Afriqy Al-Mishry (630-711 H), Lisan al-'Arab, Dar as-Shadir, Bairut, Lubnan : .... ), Juzu ke-5 , h.228

18 Abdullah Bin Muslim Bin Qutaibah Ad-Dainuri (276), Gharibi al-Qur'an, h. 246.

19 Abu Muhammad Abdurrahman Bin Muhammad Bin Idris Bin Mundzir AtTamimy Al-Hazhaly (327 H), Mu'jam al-Buldan, Al-Mamlakah As-Su'udiyyah AlArabiyyah : 1419, (Makbah Nizar Mushthafa al-Baza), Cet ke-3. h. 246 
Dalam Hadits Rasulullah SAW :

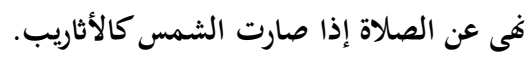

Rasulullah SAW melarang shalat apabila matahari seperti kambing yang daging perutnya besar.

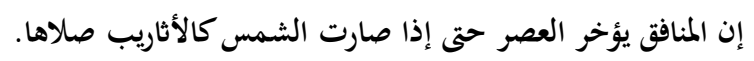

Sesunggubnya orang munafik menakhirkan shalat ashar hingga matahari seperti kambing yang daging perutnya besar.

Kata تعيير dan تأنيب dan استقصاء في اللوم seprti (mencela, memarahi, menghina). الثارب الموبخ (orang yang mencela, menegur, mendamprat). ${ }^{20}$

\section{Makna Yatsrib menurut isthilah}

Di dalam mu'jam al-Buldan Yatsrib difathahkan awalnya, dikarahkan huruf ke duanya dan disukunkan Ba-nya, Menurut Abu al-Qasim az-Zajjajy Yatsrib adalah Madinatu al-Rasul. Dinamakan seperti itu karena orang pertama yang menempati daerah itu Ytsrib Bin Qaniyah Bin Mahlayil, Bin Iram, Bin 'Abil, Bin 'Udh Bin Iram Bin Sam Bin Nuh alaibis salam. Setelah Rasulullah shallallahu 'alaibi wa sallam tinggal di sana Beliau menamainya Thaibah dan Thabah. Beliau enggan menyebut Yatsrib karena ma'na Tatsrib (tidak ada yang Bagus). Dan dinamakan Madinatur Rasul karena Rasulullah shallallahu 'alaibi wa sallam tinggal di sana. ${ }^{21}$

Ibnu Abbas berkata: "Siapa menyebut Madinah dengan nama Yatsrib maka hendaknya ia meminta ampun kepada Allah tiga kali. Sesunggubnya ia adalah Thaibah."

Nabi shallallah 'alaibi wa sallam setelah hijrah bersabda :

${ }^{20}$ Jamaluddin Muhammad Bin Mukrim Ibnu al-Manzhur Al-Afriqy Al-Mishry (630-711 H), Lisan al-'Arab, Dar as-Shadir, Bairut, Lubnan : .... ), Juzu ke-5, h.228.

${ }^{21}$ Imam Syihabuddin Abi Abdillah Yaqut Bin Abdillah al-Hamwi ar-Rumy alBaghdady (626), Juz ke-5, Libanon, Bairut : Dar al-Kutub al-'Ilmiyyah, h. 493 
Ya Allah sesungguhnya Engkau telah mengeluarkan kami dari bumi-Mu yang paling aku sukai. Maka tempatkanlah aku di bumi yang Kau sukai.

Maka Allah subbanahu wa ta'ala menempatkan Nabi shallallabu' 'alaibi wa sallam di Madinah.

Yatsrib mempunyai nama yang menandakan letaknya secara geografis, Ibnu Hurraty (Raqim) dan Barrah (yang memilikei kemerdekaan). Dan dan diantara nama-namanya dan sifat-sifatnya yang paling agung karena tertutupnya dia dan menonjolnya keutamaan dan pengaruhnya. ${ }^{22}$

Latak geografis. Kota Yatsrib terletak di sebelah utara Makkah dengan jarak $500 \mathrm{~km}$, dengan hamparan tanah yang terbuka dari segala penjuru. Lahan yang belum pernah diolah, banyak sumber air dan pepohonan dan rumah-rumah besar. Gunung yang terdekat adalah gunung Uhud yang terletak di sebelah utara Yatsrib. Berhadapan dengannya di sebelah barat -selatan terdapat gunung 'Ier. Gunung 'Ier adalah dua bukit merah dekat perut lembah 'aqiq. Yang satunya bernama 'Ier al-warid, satunya lagi 'Ier as-Shadir. Dari Yatsrib ke arah timur Baqi' al-gharqad. Ke arah selatan Quba. Ke arah selatannya lagi kampung Quba yang jaraknya sekitar 2 mil dari Yatsrib. Ke selatannya lagi ada kampong al-Qura pada lintasan menuju Makkah. Lembah Aqiq adalah tanah yang paling subur daintara tanah yang ada di Yatsrib. Dan Aqiq adalah kumpulan beberapa lembah seperti 'Aqiq al-ashfar dan lain-lain, adalah lembah yang mengaliri saluran-saluran ladang di Madinah. Daintaranya Bi'rur Rumah. ${ }^{23}$

\section{Perbukitan (pegunungan).}

Kota Madinah terletak di tengah lembah yang terbentang luas, dikelilingi perbukitan (pegunungan) dan dataran tinggi. Sebagaimana umumnya perbukitan dan dataran tinggi ini saling sambung menyambung satu dengan yang lainnya dan memiliki hubungan yang erat dengan peristiwa-peristiwa penting. Dan tempat-tempat peristiwa yang berbahaya yang terjadi di zaman rasulullah shallallabu 'alaibi wa sallam.

a. Gunung Uhud

b. Gunung 'Ainain (Bukit Rumat)

${ }^{22}$ Sayyaid Abdul-'Aziz, Tarikh al-arab, h.333. al-Jabali, Tarik al-'Arab fi alJahily, h 187. Al-Khatrawi, Al-Madinah fi ashri al-Jahily, h. 24. (Madinah Yatsrib qobla al-Islam). H. 27.

23 Yasin Ghadhban, MADINATU YATSRIB QABL AL-ISLAM. Daar al-Basyir, (Aman - Urdun : 1993), Cet. Pertama, h. 27 

c. Gunung Sila'
d. Gunung Sali'
e. Gunung Mustandir
f. 'ier dan Tsur. ${ }^{24}$

\section{Audiah (lembah-lembah).}

a. Wadil al-'Aqiq (Lembah 'Aqiq) daerah barat

b. Wadi Ranuna (Lembah Ranuna) daerah selatan-barat

c. Wadi Buthan (Lembah Buthan) daerah selatan

d. Wadi Mudzainib (Lembah Muzainib) daerah selatan -timur

e. Wadi Mahzur (Lembah Mahzur) daerah timur

f. Wadi Qanat (Lembah Qanant) daerah utara timur. ${ }^{25}$

\section{Daerah-daerah di dataran tinggi Madinah.}

a. Harrah waqim (daerah Waqim)

b. Harrah Wabarah (daerah wabarah)

c. Harrah Mudrrij (Tsaniyyatul Wada'). ${ }^{26}$

\section{Bi'r (Sumur)}

Bi'rur Rumah. Letak bi'rur Rumah dari Yatsrib ke arah utara sekitar perjalanan satu jam. Dan diantara lembah-lembah Madinah adalah lembah bathhan sebelah barat Ytasrib dan lembah ranuna mulai dari bukit 'Ier yang menghadapi Madinah dan melewati Quba kemudian bertemu dengan lembah Bathan. Dan diantara lembahnya lagi lembah Mudzainib di sebelah timur-selatan. Cabang dari lem,bah Bathan adalah lembah Qainat. Letaknya disebelah utara-timur Yatsrib. Dan lembah Mahzur di selatan-timur. Datang dari Hurrah Syarqiyyah ke hurrah Waqim. Dan di 'Atiq ada dua wilayah terbuka. Wilayah terbuka al-baqli (sayuran) dan tanah terbuka (air). Dan ada tiga dataran tinggi yang luas. Dataran tinggi Tudhari, dataran tinggi Ummu khalaid dan dataran tinggi al-'Aqir. ${ }^{27}$

Hurrah (dataran tinggi dan tanah bercampur pasir). Adapun daerah dataran tinggi dan tanahnya bercampur pasir ada tiga tempat; pertama hurrah waqim di sebelah timur ialah hurrah yang terkenal di negri

\footnotetext{
${ }^{24}$ Atsar al-Madinah, 209

25 Atsarul Madinah al-Munawwarah, h.217

${ }^{26}$ Atsarul Madinah al-Munawwarah, h.212

27 Madinatu Yatsrib qabla al-Islam. h. 28.
} 
Arab. Tananhnya yang paling subur di daerah Yatsrib. Mereka menyebutkan bahwa nama Waqim nama seorang lelaki dari Amaliq. Ada yang mengatakan bahwasanya Waqim adalah nama salah satu benteng Bani 'Abdi al-Ashal. Di tengah-tengah wilayah ini didiami oleh suku Aus diantaranya Bani al-Ashal Bani Zhufur dan Bani Mu'awiyah. Sebagaimana dahulu pernah didiami oleh qabalah-qabilah Yahudi Bani Quraizhah dan Bani Nadhir.

Rumah-rumah di Yatsrib (Raman Rasulullah). Menurut sebuah sumber bahwa rumah-rumah di Yatsrib terdiri dari bangunan dua lantai. Lantai dasar dan lantai atas. Lantai dasar mereka jadikan untuk kandang ternak-ternak mereka. Sementara lantai atas sebagai tempat tinggal mereka. Adalah rumah Abu Ayyub Al-Anshary memiliki dua tingkat. Di awal hijrah, pada waktu Rasulullah SAW tinggal untuk sementara di rumah beliau, Rasulullah SAW dan keluarga menempati lantai dasar dan Abu Ayyub alAnshari dan keluarga menempati lantai atas.

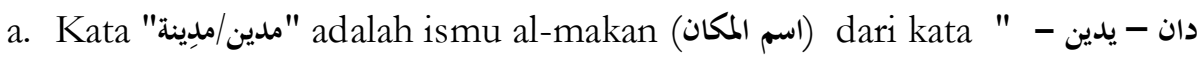
"دينا" sama dengan wazan " مفْعِل/مفعلة "yang artinya "tempat beragama, tempat kepercayaan, tempat bertaubid, tempat beribadah, tempat keshalihan, tempat bertaqwa, tempat ta' at, tempat merendabkan diri, tempat mengatur urusan, tempat pembalasan, tempat kekuasaan, tempat membuat keputusan, tempat kemenangan,

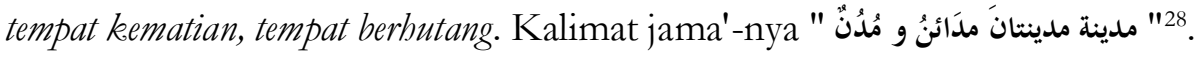

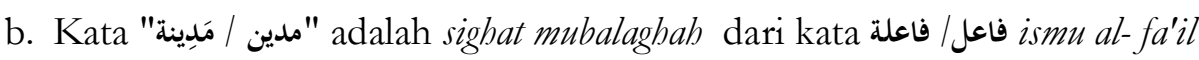

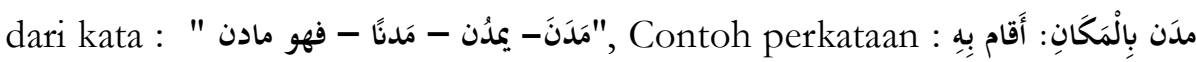
(ia tinggal / ia berdiam di tempat itu). Dari isim fa'il " مادن " dibuat kalimat

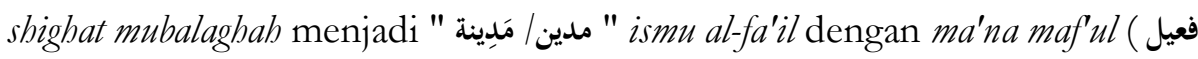

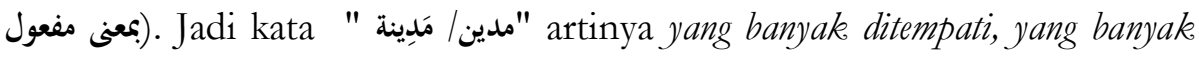
didiami atau dapat diartikan "kota".

c. Kata "مدين / مَعِيلة " diartikan juga benteng yang dibangun tinggi di atas tanah. Setiap tanah yang dibangun di atasnya bangunan

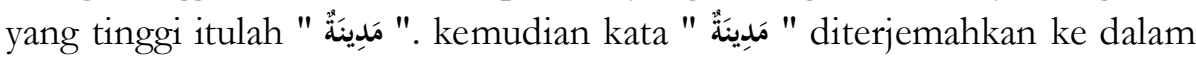

${ }^{28}$ Ahmad Warson Munawwir, Kamus Al-Munawwir, Surabaya, Pustaka Progressif : 1997, Cet: ke-4. 
bahasa Indonesia artinya "kota". Lalu kata " مَدِينيٌ " artinya penduduk kota yaitu nisbat untuk orang yang tinggal di dalamnya. Misalnya orang Madinah

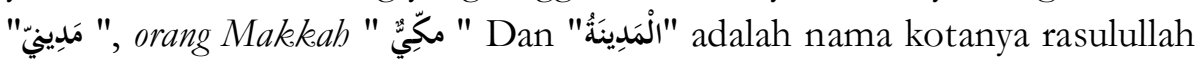

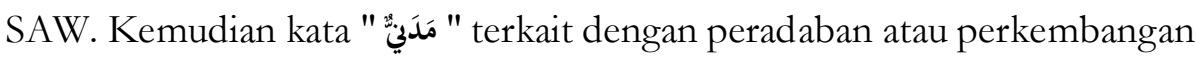

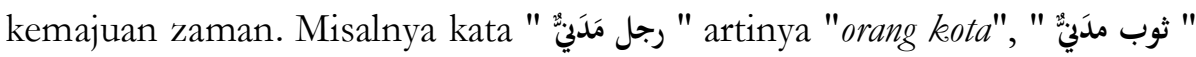

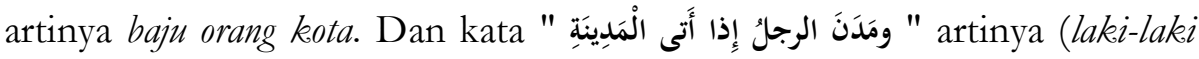
datang ke kota). ${ }^{29}$

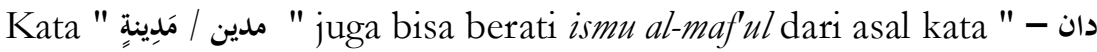

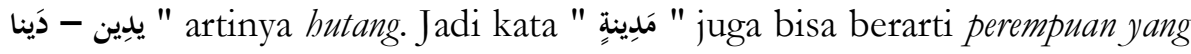

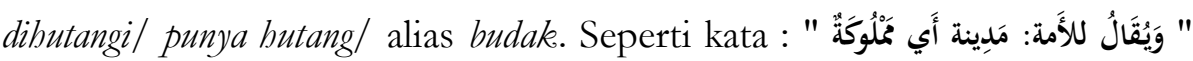
(wanita budak)

Kemudian kata "تمدُنْ " مجدَّن-يتمدن-تمدُنا " adalah ismu al-mashdar dari " sewaz̧an dengan " تفعَّل - يتفعَّل - تفعُلا "artinya mengembangkan kota. Mengembangkan peradaban.

Berikutnya kata " طابة و الطيبة " adalah ismu al-mashdar dari kata " طابة "يطيب - طيبة و طابة" yang artinya "baik/ bagus". Dan ismu al-mashdar tidak terikat dengan waktu. " طابة و الطيبة artinya baik atau selalu baik atau baike terus menerus.

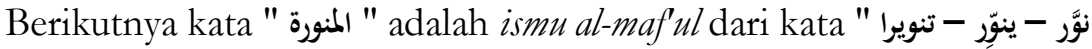
" yang artinya "disinari". Dan wazan " بناءه للتكير" adalah " فعَّل " artinya banyak atau yang disinari bertubi-tubi atau yang selalu disinari" oleh " نور "cahaya Allah.

الكتاب: لسان العرب، المؤلف: محمد بن مكرم بن على، أبو الفضل، جمال الدين ابن منظور 29

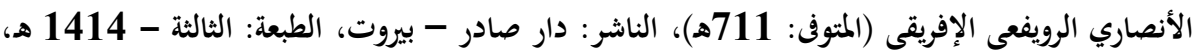

عدد الأجزاء: 15، [ترقيم الكتاب موافق للمطبوع، ومذيل بحواشي اليازجي وبماعة من اللغويين]. 
Yatsrib diganti namanya oleh Allah SWT menjadi Madinah sebelum Rasulullah SAW hijrah dan tinggal di sana. Setelah Rasulullah Saw tinggal di Madinah mempuyai nama sebanyak 94 nama, :

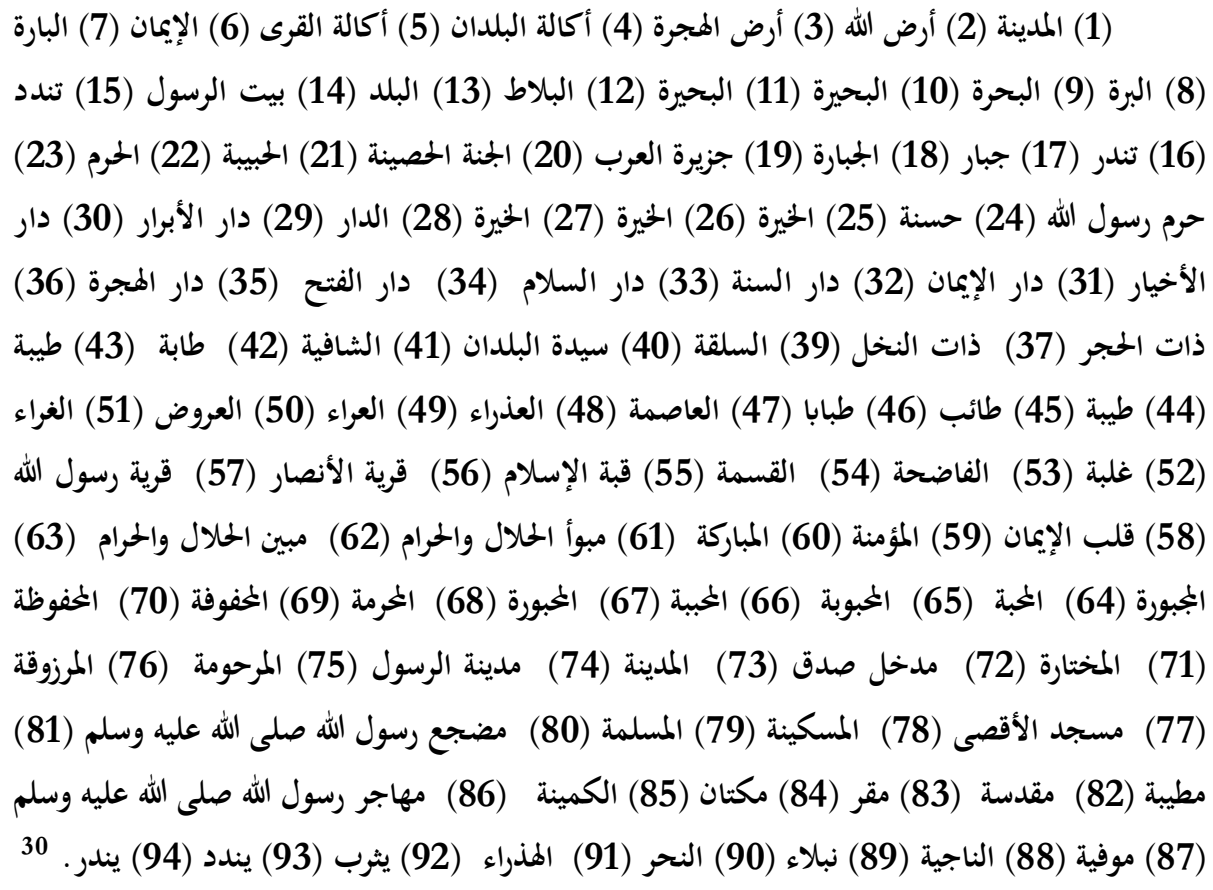

Jangan kita membayangkan Madinah pada masa 1400 tahun silam atau di zaman Rasulullah shallallabu 'alaibi wa sallam tinggal di sana, seperti Madinah yang kita lihat sekarang ini. Tentu sangat jauh berbeda. Menurut sumber-sumber yang penulis temukan, Madinah dikelilingi delapan lembah yang merupakan sumber air yang mengaliri ladang-ladangnya melalui sailsail (sungai-sungai kecil). Jadi 1400 tahun silam Madinah itu adalah daerah yang sangat ideal untuk hunian. Sebab semuanya ada di Madinah. Dikelilingi pegunungan banyak lembah-lemah sebagai waduk air, ada beberapa sungai-sungai kecil yang terhubung dari lembah ke ladang-ladang. Ada daerah-daerah pertaian bertanah basah dan ada daerah-daerah perkebunannya dan ada pula daerah yang agak tinggi dan datar yang disebut

${ }^{30}$ Nuruddin Ali Bin Abdullah As-Samhudi $(911 \mathrm{H})$, WAFA AL-WAFA BI AKHBARI DAR AL-MUSHTHAAFA, Makkah-Madinah Al-Munawwarah : Muassah al-Furqan Lit Turas al-Isllamy, h. 61 - 91 
barrah. Ada dataran sedang. Bahkan ada hutannya dengan pepohonan sangat lebat. Waktu itu yang terkenal dengan nama Ghabah (hutan yang ada di barat-utara Madinah). Udara di Madinah pun sangat bagus sekali. Satu lagi tidak boleh kita lupakan bahwa Madinah adalah daerah yang dipenuhi pohon kurma di mana-mana. Makanya Madinah disebut أرض ذات نخل (daerah yang memiliki pohon-pobon kurma)

Adapun pembangunan Madinah yang dapat kita jadikan contoh sebagai konsep Community Development yang kemudian menjadi acuan bagi negara-negara Islam yaitu antara lain :

\section{Pembangunan Masjid Quba}

Rasulullah shallallabu 'alaibi wa sallam beragkat hijrah dari rumahnya menurut beberapa pendapat ulama yaitu malam jum'at lalu ke rumah Abu Bakkar Ash-Shiddik di Misfalah dan malam itu juga berangkat ke guha Tsur yang ada di selatan Makkah. Rasulullah shallallahu 'alaibi wa sallam berdiam di guha Tsur hari Jum'at sampai malam Senin. Setelah tiga hari tiga malam, maka pada malam Senin tanggal 1 Rabi'ul Awwal sebagaimana yang telah di rencanakan Rasulullah shallallahu 'alaibi wa sallam berangkat dari guha Tsur menuju Madinah melewati jalur yang jarang dilewati orang. Dekat pesisir laut Merah. Rasulullah shallallabu' alaibi wa sallam hijrah ditemani oleh Abu Bakrin Ash-shiddiq, Amir Bin Puhairah (khadimu Abu Bakrin - ia berngkat untuk melayani keduanya) dan Abdullah Bin Uraiqit (sang penunjuk jalan yang diupah). ${ }^{31}$

Kemudian setelah menempuh perjalanan lebih kurang 8 malam dan 8 hari, sampailah Rasulullah shallallabu 'alaibi wa sallam di Quba dari arah kampung Tsaniyyatul Wada'. Sekita 500 orang dari penduduk asli Madinah dan orang-orang Muhajirin yang telah sampai lebih dahulu menyambut Rasulullah shallallabu 'alaibi wa sallam dengan sangat gembira. Mengapa mereka sangat gembira ? karena penduduk Madinah berharap dengan hijrahnya Rasulullah shallallahu 'alaibi wa sallam ke Madinah mereka akan mempunyai masa depan yang baik di bawah kepemimpinan Rasulullah shallallahu 'alaibi wa sallam, diharapkan akan dapat mendamaikan suku Aus dan Khajraj yang telah lama saling berperang, membawa keadilan dan

31 Shafiyyurrahman Al-Mubarakfury, AR-RAHIQI AL-MAKHTUM, SIRAH NABAWIYYAH, Pustaka Al-Kautsar (Jakrta : 1997), h. 226. 
ketentraman bagi kehidupan mereka. Sementara ada yang tidak senang dengan kedatangan Rasulullah shallallahu 'alaibi wa sallam yaitu orang-orang Yahudi dan Nashrani yang ada di Madinah termasuk Abdullah Bin Ubay yang sebenarnya sudah disepakati oleh suku Aus dan Khajraj untuk menjadi pemimpin mereka. Dengan kedatangan Rasulullah shallallabu'alaibi wa sallam ke Madinah maka pupuslah harapan Abdullah Bin Ubay menjadi Pemimpin Madinah.

Rasulullah shallallahu 'alaibi wa sallam tinggal di Quba di perkampungan Bani Amr Bin Auf. Menurut Ibnu Zubalah Rasaulullah shallallahu 'aibi wasallam menetap di Bani Amar Bin 'Auf 22 hari. ${ }^{32}$ Pendapat lain ada yang mengatakan hanya sekitar 4 hari 4 malam kurang lebih. Menurut pendapat yang lebih shahih. Yaitu mulai senin pagi tanggal 8 Rabiul Awwal sampai Jum'at pagi 12 Rabiul Awwal.

Selama lebih kurang lebih 4 hari 4 malam itu Rasulullah shallallabu 'alaibi wa sallam membuat satu program yaitu memulai pembangunan masjid Quba. Jadi program pertama yang dilakukan oleh Rasulullah shallallahu 'alaibi wa sallam ialah membangun masjid. Ini artinya bahwa setelah sampai di dar al-bijtah Rasulullah shallallahu 'alaibi wa sallam langsung mengimplementasikan ardhu al-Hijrah sebagai tempat melaksanakan keyakinan kepada Allah subhanabu wa ta'ala. Sebagai tempat melaksanakan ketaqwaan kepada Allah subbanahu wa ta'ala. Sebagai tempat leksanakan ajaran agama Islam.

Kemudian pada hari juma'at pagi tanggal 12 Rabiul Awwal Rasulullah shallallahu 'alaibi wa sallam berangkat menuju perkampungan Bani Najjar. Perkampungan tempat tinggal kerabat Rasulullah shallallabu' alaibi wa sallam baik dari ibundanya maupun dari neneknya. Sebelum ke perkampungan Bani An-Najjar Rasulullah shallallahu 'alaibi wa sallam mengirim utusan ke sana. Dan pada hri jum'at itu lebih kurang 100 orang dari Kaum Bani Najjar menjemput Rasulullah shallallahu 'alaibi wa sallam dengan pedang terhunus. Yang artinya siap membela dan melindungi Rasulullah shallallabu 'alaibi wa sallam.

a. Shalat Jum'at yang Pertama kali

Sesampainya rombongan Rasulullah shallallabu 'alaibi wa sallam di kampong Bani Salimah di lembah Ranuna tibalah waktu shalat Jum'at. Lalu

${ }^{32}$ Muhammad Bin Hasan Bin Zabalah (199H), AKHBAR AL-MADINAH, Markaz Buhuts wa Dirasat, (Madinah al-Munawwarah : 2003 M/ 1424), h. 71, 
Rasulullah shallallabu 'alaibi wa sallam bersama rombongan menunaikan shalat jum'at di situ. Inilah shalat jum'at pertama yang dilakukan Rasulullah shallallabu 'alaibi wa sallam.

Shalat jum'at merupakan ibadah jam'iyyah. Dengan melaksanakan shalat jum'at dapat dima'nai bahwa Rasulullah shallallahu 'alaibi wa sallam telah melakukan ibadah secara berjama'ah dengan kelompok besar. Sehingga nuansa religious lansung dirasakan oleh orang Madinah dan Muhajirin. Tentu saja keharuan dan kebahgiaan orang-orang yang ada di Madinah semakin bertamabah-tambah. Karena hal semacam itu belum pernah terjadi dalam kehidupan mereka. Apalagi tentunya mendengar bacaan al-qur'an Rasulullah shallallahu' alaibi wa sallam dalam shalat jum'at. Maka hati siapa yang tidak terharu. Pelaksanaan shalat jum'at ini tentunya banyak sekali mengandung ma'na dan pelajaran bagi kehidupan kita. Apalagi bagi masyarakat Madinah yang baru pertama kali mengalami ibadah semacam itu. Tentunya tak bisa kita lukiskan keharuan, kegembiraan, ketakjuban dan segala macam perasaan kegembiraan dan kepuasan ruhaniyah mereka. Pepuasan sepiritual yang bisa menggelorakan semangat yang ada di dalam jiwa.

\section{Pembangunan Masjid Nabawi sebagai markaz Islam (pusat peradaban Islam di mulai)}

Selepas melaksanakan shalat jum'at Rasulullah shallallabu 'alaibi wa sallam bersama rombongan melanjutkan perjalanan ke kampung Bani Najjar yang jaraknya dari Quba 3 mil $(5,4 \mathrm{~km})$. Sesampainya di kampaung Bani Najjar Rasullullah shallallabu 'alaibi wa sallam di tempat untanya menderum di situlah Beliau membangun masjid sebelumnya beliau membeli terlebih dahulu kebun tersebut dari dua orang anak Yatim. Setelah selesai urusan pembelian tanah barulah beliau memerintahkan para shahabat membersihkan kebn tersebut dari pepohonan dan beberapa kuburan orang kafir.

Pembangunan Masjid yang kemudian disebut masjid Nabawai ini bagi pengembangan masyarakat Islam bermakna markaz. Islam (pusat Islam). di sainila nantinya titik pusat peradaban ditancapkan, Islam dimulai dan dikembangkan di muka bumi Allah yang baik (Thaibah);

1) Pembangunan sarana ibadah. 
Pembengunan masjid juga merupakan pembangunan sarana Ibadah. Hal ini di dahulukan oleh rasulullah shallallabu 'alaibi wa sallam karena menjadi yang terpenting bagi pembangunan peradaban Islam sebagai bentuk penguatan hubungan vertical kepada Allah subhanabu wa ta'ala, sebagai bentuk pembuktian keimanan kepada Allah subhanahu wa ta'ala, tempat melaksanakan ketaqwaan keapda Allah subhanabu wa ta'ala yang paling utama yaitu shalat. Dan juga sebagai penguatan hubungan horizontal sesama manusia. Karena masjid nantinya akan menjadi tempat berkumpulnya ummat Islam dengan intensitas yang sangat tinggi yaitu lima kali sehari. Bagi yang jauh sekurang-kurangnya sejum'at sekali. Masjid juga sebagai tempat syi'ar islam, I con (lambang) Islam.

Tentu saja fenomena ini memberikan pengaruh spiritual yang sangat besar, yang bisa dirasakan setiap anggota masyarakat, karena mereka menjadi pendamping Rasulullah shallallahu 'alaibi wa sallam. Sementara itu beliau sendir yang mengajari, mendidik, membimbing, mensucikan jiwa manusia, menuntun mereka kepada akhlak yang baik, menanamkan adab kasih saying, persaudaraan, kemuliaan, ibadah dan ketaatan.

2) Sarana da'wah

Masjid Nabawi merupakan sarana da'wah dengan multifungsi. Sebagai saranan pendidikan sarana pembinaan masyarakat (ummat). Karena di masjid Nabawi-lah pendidikan ummat dilaksanakan ummat dibina di bawah tuntunan wahyu setiap saat. Terutama setelah selesai melaksanakan shalat. Meskipun hanya dengan system mendengarkan, tetapi begitu banyak shabat yang hafal al-qur'an dan hadits Rasulullah shallallahu 'alaibi wa sallam. Bahkan murid-murud rasulullah shallallabu'alaibi wa sallam banyak yang menjadi orang besar, mampu menjadi pemimpin dunia yang sukses, menjadi kahlifah yang kepemimpinannya seluas jaziarah arabia. Keberhasilan pendidikan Rasulullah shallallabu 'alaibi wa sallam tercatat dalam lembaran-lembaran sejarah dengan tinta emas. Tidak pendidikan yang lebih berhasil dari pada pendidikan rasulullah shallallahu 'alaibi wa sallam dari masjid yang sangat sederhana.,

3) Sarana Pemerintahan (Kantor Pusat Pemerintahan) 
Masjid Nabawi juga sebagai sarana pemerintahan, kantor besar di mana semua urusan diatur di situ. Semua urusan pemerintahan dibicarakan dan diputuskan di masjid. Masjid Nabawi laksana kantor Pusat kepresidenan. Dan semua pejabat departemen berkantor di situ. Pemerintahan yang dijalankan Rasulullah shallalabu 'alaibi wa sallam adalah pemerintahan yang sangat maju. Surat-menyurat Rasulullah shallallahu 'alaibi wa sallam sudah memakai stempel resmi. Yaitu cincin beliau yang bertuliskan Muhammad Rasulullah. Entah di dapat dari mana cicin tersebut, penulis belum mendapatkan sumbernya tentang hal ini tetapi bukti surat-surat Rasulullah shallallabu 'alaibi wa sallam berstempel cincin beliau yang bertuliskan Muhammad Rasulullah itu bisa kita temukan dalam manuskrip-manuskrip.

4) Balai Pertemuan sekaligus Balai musyawarah atau Gedung Parlemen

Masjid Nabawi juga kemudian berfungsi sebagai balai pertemuan. Pertemuan apa saja dilaksanakan di masjid Nabawi ini. Selain pertemuan jama'ah shalat juga pertemuan-pertemuan urusan selain shalat. Sepeerti urusan pemerintahan, kemasyarakatan bahkan untuk menerima tamu yang datang dari negri jauh. Bahkan sebagai goes house. Bila ada tamu yang datang dari jauh dan bermalam, maka tempat bermalamnya adalah di masjid. Di emperan masjid bersama shahabat-shahabat muhajirin yang tidak memiliki tempat tinggal.

5) Rumah Tinggal Ahlus Suffah.

Masjid Nabawi juga berfungsi sebagai tempat tinggal para shahabat Muhajirin yang tidak memeiliki tempat tinggal seperti Abi Hurrairah, Salman al-Farisi dan lain-lain. Menurut Ibnu Hisyam ada 79 orang shahabat yang dinamakan ahlus suffah yang tempat tinggalnya di masjid. Jumlah tersebut akan bertambah manakala ada tamu yang menginap dan berkurang manakala ada yang keluar menunaikan tugas atau ada yang meninggal. Tidak dijelaskan waktu pertama kali masjid Nabawi di bangun, di emperan sebelah mana tempat tinggal mereka tetapi menurut ... dalam kitab buyutu as-shahabah haula masjid asy-syarif, setelah perubahan kiblat yang sebelumnya menghadap ke utara, arah masjid al-aqsha, kemudian mihrab dan 
pengimaman di pindah menhadap ke selatan ke arah masjid al-haram (Makkah), maka bekas mihrab dan pengimaman yang lama dilarang dibongkat oleh Rasulullah Ishallallabu 'alahi wa sallam, dan difungsikan untuk tempat tinggal para ahlus shuffah.

6) Istana Rasulullah shallallabu 'alaibi wa sallah dibangun di samping masjid.

Jika kita shalat di masjid Nabawi di dekat pengimaman, maka sebelah kiri kita itu adalah rumah rasulullah shallallabu 'alaibi wa sallam. Yang paling dekat dengan masjid rumahnya Siti 'Aisyah radiyallabu 'anha, sekarang yang ada makam Rasul. Jarak anatara mimbar dengan rumah 'Aisyah radhiyallabu 'anha (rumah rsulullah shallallabu 'alaibi wa sallam) adalah 30 meter. Di situllah istana Rasulullah shallallahu 'alaibi wa sallam.

b. Mempersaudarakan Kaum Muhajirin dengan Anshar

Menurut riwayat Ibnu Ishaq program at-takh-khi (mempersaudarakan) kaum muhajirin dengan Anshar adalah dilakukan 8 hari setelah sampainya Rasulullah shallallahu 'alaibi wa sallam di Madinah. Ada juga pendapat yang mengatakan sebelum 8 hari. Dan ada juga yang mengatakan 6 bulan setelah sampainya Rasulullah shallallabu' alaibi wa sallam di Madinah. Pendapat yang paling shahih adalah 8 hari setelah sampainya Rasulullah shallallahu 'alaibi wa sallam di Madinah. Alasannya karena program persaudaraan ini dibuat untuk mengatasi persoalan antara lain ; membantu kaum muhajirin yang membutuhkan bantuan baik makanan maupun tempat tinggal. Karena mereka datang ke Madinah ada yang tidak membawa apa-apa. Maka dengan program persaudaraan ini, orang-orang anshar yang sudah dipersaudarakan dengan orang Muhajirin tidak hanya saling berbagi makanan tetapi mereka mau saling berbagi harta bahkan rela menceraikan istrinya (bagi yang memiliki istri lebih dri satu) untuk dinikahkan kepada saudaranya dari Muhajirin. Bahkan sampai mau mewarisi hartanya ketika ia meninggal. Ada 90 orang kaum muslimin yang dipersaudarakan. Ada yang dipersaudarakan antara Muhajirin dengan Anshar. Ada yang dipersaudarakan antara Anshar dengan Anshar, Muhajirin dengan Muhajirin guna untuk menghilangkan perasa lebih tinggi derajatnya atau merasa lebih rendah dan lain sebagainya. Program taakh- 
khi ini tidak hanya mempersatukan, menguatkan perstuan dan kesatuan sebagai sesame muslim, tetapi sebuah solusi yang brillian dari Rasulullah shallallabu 'alaibi wa sallam untuk mengatasi keadaan kaum Muhajirin yang terlunta-lunta, nelangsa dan sengsara menjadi berdaya karena mereka diangkat derajatnya dan diberdayakan oleh saudaranya kaum Anshar. Maka ketahanan social yang sebelumnya rapuh menjadi kokoh. Berat sama dipikul ringan sama dijinjing. Bahu membahu membangun masyarajat baru, membela agama Allah mendukung da'wah Rasulullah shallallabu 'alaibi wa sallam.

c. Perjanjian antara sesama muslim.

Dengan mempersaudarakan orang-orang mu'min itu, Rasulullah shallallahu 'alaibi wa sallam telah mengikat suatu perjanjian yang sanggup menyingkirkan belenggu jahiliyyah dan fanatisme kekabilahan, yang akan merugikan bagi persatuan dan kesatuan ummat. Tetapi hal itupun masih dianggap kurang oleh rasulullah shallallahu 'alaibi wa sallam, kaum muhajirin dan Anshar masih perlu diikat dengan perjanjian yang kuat. Bunyi perjanjian tersebut sebagai berikut :

"Ini adalah perjanjian dari Nabi Muhammad shallallabu 'alaibi wa sallam, berlaku di antara orang-orang mu'min dan muslim dari quraisy dan dari Yatsrib serta siapapun yang mengikuti perjanjian mereka, menyusul di kemudian hari dan yang berjihad bersama mereka :

1) Mereka adalah ummat satu di luar golongan yang lain.

2) Muhajirin dari quraisy dengan adatkebiasaan yang berlaku diantara harus saling bekerj sana dalam menerima atau membayar suatu tebusan. Sesame orang mu'min harus menebus orang yang ditawan dengan cara yang ma'ruf dan adil. Setiap kabilah dari Anshar dengan adat kebiasaan yang berlaku di kalangan mereka harus menebus tawanan sendiri, dan setiapgolongan di antara orang-orang mu'min harus menebus tawanan dengan ma'ruf dan adil.

3) Orang-orang mu'min tidak boleh meninggalkkan seseorang yang menanggung beban hidup diantara sesama mereka dan memerinya dengan cara yang ma'ruf dalam membayar tebusan atau membebaskan tawanan. 
4) Orang-orang mu'min yang bertaqwa harus melawan orang-orang yang berbuatzhalim, berbuat jahat dan kerusakan di anatara mereka sendiri.

5) Secara bersama-sama mereka harus melawan orang-orang yang seperti itu, sekalipun di anak seseorang di antara mereka sendiri.

6) Seorang mu;min tidak boleh membunuh orang mu'min lainnya karena membela orang kafir.

7) Seorang mu'min tidak boleh membantu orang kafir dengan mengabaikan orang mu'min lainnya.

8) Jaminan Allah adalah satu. Orang paling lemah diantara mereka pun berhak mendapat perlindungan.

9) Jika ada oeang Yahudi yang mengikuti kita, maka mereka berhak mendapat pertolonga dan persamaan hak, tidak boleh dizhalimi dan ditelantarkan

10) Perdamaian yang dikukuhkan orang-orang mu'min harus satu. Seorang mu'min tidak boleh mengadakan perdamaian sendiri dengan selain mu'min dalam suatu peperangan $f i$ sabilillah. Mereka harus sama-sama dan adil.

11) Sebagian orang mu'min harus menampung orang mu'min lainnya, sehingga darah mereka terlindungi fi sabilillah.

12) Orang musyrik tidak boleh melindungi harta orang quraisy dan tidak boleh merintangi orang mu'min.

13) Siapapu yang membunuh orang mu'min yang idak bersalah, maka dia harus mendapat hukuman yang setimpal, kecuali jika wali orang yang terbunuh merelakannya.

14) Semua orang mu;min harus bangkit untuk memela dan tidak boleh diam saja.

15) Orang mu'min tidak boleh membantu dan menampung orang yang jahat. Siapa yang melukannya, maka dia berhak mendapt la'nat Allah dan kemurkaan-Nya pada hari kiamat dan tiadak ada tebusan yang dapat diterima.

16) Perkara apapun yang kalian perselisihkan, harus dikembalikan kepada Allah dan Muhammad shallallahu 'alaibi wa sallam.

Dengan perjanjian tersebut kaum muslimin di Madinah sebagai masyarakat yang baru saja terbentuk tatanannya menjadi kuat. Bahu- 
membahu, saling melindungi, salaing memberi, saling menyantuni, saling menyayangi, saling menjaga. Pada akhirnya persatuannya menjadi kokoh.

\section{d. Perjanjian Antara Kaum Muslimin dengan Non Muslim}

Setelah nabi shaallallabu 'alaibi wa sallam hijrah ke Madinah dan berhasil memancangkan sendi-sendi masyarakat Islam yang baru, dengan kesatuan akidah politik dan system kehidupan diantara -orang-orang muslim, maka beliau merasa perlu mengatur hubungan dengan golongan selain muslim. Perhatian beliau saat itu terpusat untuk menciptakan keaman, kebahagiaan dan kebaikan bagi semua manusia, mengatur kehidupan di Madinah dalam suatu kesepakatan. Untuk itu beliau menerapkan undang-undang yang luas dan penuh tenggang rasa, yang tidak pernah terbayangkan dalam kehidupan dunia yang selalu dibayangi dengan.

Tetangga yang paling dekat dengan orang-orang muslim di Madinah adalah orang-orang Yahudi. Dan Rasulullah shallallabu 'alabi wa sallam telah merasakan bahwa sebenarnya di dalam hati mereka menyimpan kebencian dan permusuhan terhadap orang-orang muslim, namun mereka tidak berani menmpakkannya. Beliau menawarkan perjanjian kepada mereka, yang intinya memberika kebebasan menjalankan agama dan mengelola kekayaan mereka. Perjanjian ini sendiri dikukuhkan setelah pengukuhan perjanjian di kalangan orang-orang muslim. Inilah butir-butir perjanjiannya sebagai berikut :

1) Orang-orang Yahudi Bani Auf adalah satu ummat dengan orangorang mu'min. bagi orang-orang Yahudi agama mereka dan bagi orang-orang muslim agama mereka, termasuk pengikut-pengukut mereka dan diri mereka sendiri. Hal ini juga berlaku bagi orangorang Yahudi selain Bani 'Auf.

2) Orang-orang Yahudi berkewajiban menanggung nafkah mereka sendiri, begitu pula orang-orang muslim

3) Mereka harus bahu-membahu dalam menghadapi musuh yang hendak membatalkan perjanjian ini.

4) Mereka harus saling nasihat-menasihati, berbuat baik dan tidak boleh berbuat jahat.

5) Tidak boleh berbuat jahat terhadap orang yang sudah terikat dengan perjanjian ini.

6) Wajib membantu orang yang dizhalimi. 
7) Orang-orang Yahudi harus berjalan seiring dengan orang-orang Mu'min selama mereka dalam peperangan.

8) Yatsrib adalah kota yang dianggap suci oleh orang yang menyetujui perjanjian ini.

9) Jika terjadi sesuatu ataupun perselisihan di antara orang-orang yang mengakui perjanjian ini, dan dikhawatirkan menimbulkan kerusakan, maka tempat kembalinya adala Allah dan Muhammad shallallabu' alaibi wa sallam.

10) Orang-orang quraisy tidak boleh mendapat perlindungan dan tidak boleh ditolong.

11) Mereka harus salig tolong-menolong dalam menghadapi orang yang hendak menyerang Yatsrib.

12) Perjanjian ini tidak boleh dilanggar kecuali memang dia orang yang zhalim atau jahat.

Dengan disahkannya perjanjian ini, maka Madinah dan sekitarnya seakan-akan merupakan suatu negara yang yang berdaulat, memiliki institusi, undang-undangnya dibawah naungan wahyu ilahi, ibukotanya Madinah dan presidennya adalah Rasulullah shallallabu 'alaibi wasallam. Mayoritas rakyatnya orang-orang muslim, sebagian (minoritas) Yahudi dan Nasrani. Sehingga dengan begitu Madinah benar-benar menjadi ibukota negara Islam.

\section{e. Penerapan Hukum Islam}

Di Madinah ini jelas peraturannya bersumber dari wahyu Allah. Setiap persoalan yang muncul dijawab oleh peraturan wahyu ilahy. Yang menerapkanya ialah utusan Allah. Satu contoh; Penyebab turunnya surat An-Nisa ayat 65 menjadi pelajaran bagi kita bahwa penerapan hukum syar'i dalam menyelesaikan maslah yang terjadi di lapangan da'wah adalah bagian dari kerja da'wah. Kita dapat melihat bagimana rasulullah shallallabu' 'alaibi wa sallam menjadi hakim yang wajib diterima keputusannya bagi semua orang beriman. Bahakan jika meresa keberatan atau tidak ikhlas dalam menerima keputusannya dinyatakan termasuk orang yang tidak beriman. Mari kita perhatikan firman Allah subbanabu wa ta'ala berikut ini :

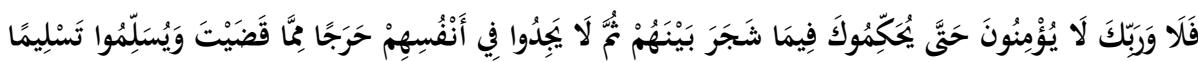
(النساء : 65 ) 
Maka demi rabbmu, mereka (pada bakikatnya) tidak beriman sebingga menjadikan kamu sebagai hakim dalam perkara yang mereka perselisibkan, kemudian mereka tidak merasa keberatan dalam hati mereka terbadap keputusan yang kamu berikan dan mereka menerima dengan sepenubnya.

Sebab turunnya ayat di atas diriwayatkan dari Imam-imam yang enam dari Abdullah Bin Zuabair, ia berkata : telah terjadi pertengkaran antara Zubair dengan seorang dari kaum Anshar di Syiraj al-Hurrah, maka nabi shallallahu 'alaibi wa sallam bersabda: airi ladangmu wahai Zubai kemudian (bila sudah cukup), alirkan airnya kepada tetanggamu (ladang yang ada di sebelah ladangmu). Lalu orang Anshar tersebut (tidak menerima keputusan itu dan) berkata : ya Rasulullah apakah (keputusan seperti itu) karena dia anak bibimu (kerabatmu) ? maka wajah Rasulullah shallallabu 'alaibiwa sallam memerah lalu mengatakan : airi ladangmu ya Zubair kemudian tahanlah (bendunglah) samapai naik ke dinding (kolam), kemudian kembalilah air itu naik dinding (kolam). Kemudian kembalilah (berbaliklah) air ltu ke tetangga (yang sebelumnya). Dan tercukupilah hal-haknya Zubair. Dan adalah ia memberi isyarat kepada keduanya bahwa perkara keduanya mengandung ma'na yang luas. Zubai berakata : aku mengira bahwa ayat ini hanya turun untuk itu.

Yang perlu kita garis bawahi adalah bahwa pada saatnya seorang da'i dituntut menjadi pemutus perkara atau hakim. Maka hendaklah merujuk kepada al-qur'an dan al-hadits serta sumber-sumber dasar pengambailan hukum syar'i. Oleh karena itu seorang da'i harus memiliki beka yang cukup ketika terjun ke lapangan da'wah. Atau paling tidak seorang da'i harus terus belajar memperkaya diri dengan keilmuan sesuai bidangnya masing-masing.

Dalam kasus lain rasulullah shallallahu 'alaibi wa sallam memberika panduan hukum dalam perniagaan. Bahwa seorang muslim dilarang keras menipu pembeli. Hadits dalam riwayat Imam Muslim dapat kita telaah secara cermat untuk kita ambil pelajaran, sebagai berikut :

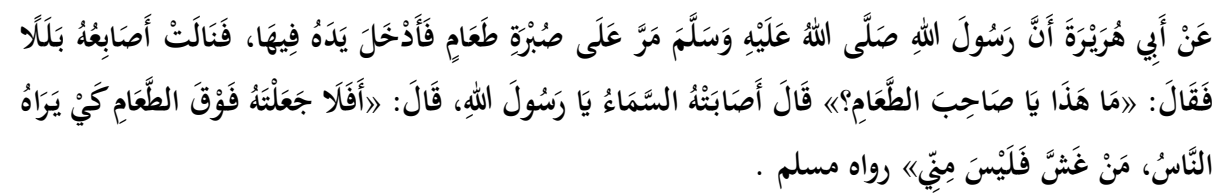


Dari Abi Hurairah Rashiyallabu 'anbu Babwasanya Rasulullab shallallabu 'alaibi sallam lewat pada sebuh tumpukan makanan (yang belum ditimbang), lalu beliau memasukkan tangannya ke dalam tumpukan makanan tersebut, maka jarijarinya basah (padahal dari luar tampak makanan itu kering). Beliau berkata : mengapa ini wahai pemilik makanan. (pemiliknya menjawab) : itu kebujanan ya Rasulullah. Rasulullah berkata : mengapa kamu tidak menaruh yang basah itu di bagian atas agar supaya orang melihat. (beliau bersabda) : siapa yang menipu dai tidak termasuk golongan kami. ${ }^{33}$

Seorang da'i harus bersikap tegas dan langs ung memberikan arahan amar ma'ruf dan nahi munkar bilaman melihat atau mendapatkan suatu perbuatan mad'u yang menyalahi syari'at.

\section{f. Progaram ketahanan sosial}

Ketahan sosial anatara lain faktornya adalah adanya ketersediaan bahan makanan dan rendahnya gap antara si miskin dan si kaya. Ketika terjadi gap yang terlalu jauh, misalnya di sebagian masyarakat sangat kekurangan bahkan kelaparan, sementara sebagian yang lainnya berkecukupan, maka akan dapat memicu kerawanan sosial dan menimbulkan kekacauan di masysrakat. Bisa jadi masyarakat yang imannya masih rendah apalagi yang tidak beriman, akan menghalalkan segala cara untuk bisa mengatasi kelaparannya. Mencuri, menipu atau bahkan merampok dan membunuh mungkin saja terjadi. Dalam hal ketahan sosial seorang da'i juga harus juga memahami di bidang tersebut. Sebab pemberdayaan ekonomi ummat muthlak menjadi tugas dan tanggung jawab da'i juga.

Dalam hal ini mari kita lihat bagaimana rasulullah shallallahu' alaibi wa sallam mengambil langkah-langkah agar orang-orang Muhajirin tidak kelaparan di negri hijrahnya. Rasulullah shallallabu 'alaibi wa sallam ketika itu baru saja sampai di Madinah. Beliau melihat ada masalah besar yang dihadapi orang-orang Muhajirin yaitu bagimana mereka memulai kehidupannya di Madinah. Karena banyak diantara mereka yang tidak punya bekal untuk hidup. Kemudian Rasulullah membuat satu program

33 H.R. Muslim. 
untuk mengatasi masalah yang dihadapi oleh orang-orang Muhajirin itu, sauatu program terobosan yang sangat brilian yaitu at-taakh-khi bainal mubajirin wal anshar (persaudaraan antara muhajirin dengan Anshar). Dengan persaudaraan ini antara Muhajirin dengan Anshar tidak hanya sekedar rela berbagi makanan dan harta, akan tetapi sampai mau saling mewarisi. Ada 90 orang Muhajirin dan Anshar yang dipersaudarakan oleh Rasulullah shallallahu 'alaibi wa sallam. Dari kaum Muhajirin sebagian dan dari kaum Anshar sebagiannya. Peristiwa persaudaraan ini terjadi sebagian pendapat mengatakan hari ke delapan setelah rasulullah shallallabu'alaibi wa sallam sampai di Madinah, ada yang mengatakan sebelumnya, ada yang mengatakan lima bulan sesudahnya. Sebagamana diriwayatkan ileh Ibnu Hisyam. ${ }^{34}$

Tidak terbayangkan oleh penulis sebelumnya, bahwa ternyata Madinah adalah negri agraris (daerah pertanian) sebagian besar penduduknya hidup dengan bercocok tanam.

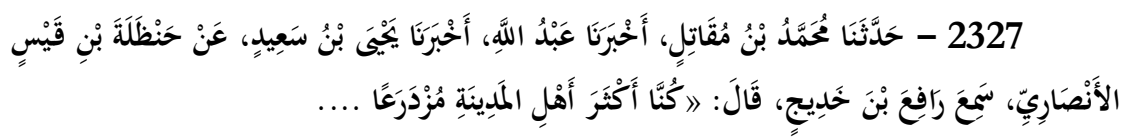

Mubammad Bin Muqati telah memberitakan kepada kami, (ia berkata); Abdullah telah memberitakan kepada kami (ia berkata) : Yahya Bin Sa'ad telah memberitakan kepada kami (ia berkata) : dari Hanzhalah Bin Qais al-Anshary kami pernah mendengar Rafi' Bin Khadij, Ia berkata : Kami penduduk Madinah dabulu adalah petani ..... ${ }^{35}$

Sebagaimana telah penulis jelaskan sebelumnya bahwa daerahnya dikelilingi lembah-lembah yang mengairi ladang-ladangnya melalui sail-sail (aliran-aliran kecil). Ternyata begitu banyak penulis dapatkan hadits-hadits

${ }^{34}$ Nuruddin ali Bin Abdullah as-Samhudy ()911 h, WAFA AL-WAFA LI AKHBARI ALMUSHTHAFA, (Makkah dan Madinah : $2001 \mathrm{M} / 1422 \mathrm{H}$ ) : Muassasah al-Furqan li at-turats al-islamiyyah, Cet. Ke-1 jilid 1, h. 457.

35 Al-Imam Ibnu Hajar Al-'Asqallany (773-852 H), FATHU AL-BARY BISYARHI SHAHIHI AL-BUKHARY, Daar al-Hadits, (al-Qahirah : 1424 H/2004 M) Zuzu 5. H. 12. 
rasulullah shallallabu'alaibi wa sallam yang berbicara soal pertanian. Ketika rasulullah shallallahu 'alaibi wa sallam mempersaudarakan kaum Muhajirin dengan kaum Anshar, banyak orang Anshar yang ingin memberikan hartanya kepada kaum Muhajirin. Tetapi kebanyakan kalangan Muhajirin menolak pemberian tersebut dan lebih memilih kerjasama dalam pertanian. Baru kemudian orang Muhajirin mau mengambil bagian dari hasil pertanian sesuai baginnya yang ma'ruf.

Salah satu bentuk pelaksanaan at-takhkhi kerjasama di bidang pertanian. Sebab kaum Muhajirin banyak yang menolak pemberian orang Anshar secra Cuma-Cuma. Akan tetapi mereka abru mau menerima pemberian Anshar jika mereka telah bekerja untuk orang Anshar. Al-Imam Ibnu Hajar al-'asqallany dalam kitab Fathu al-Bary-nya meriwayatkan :

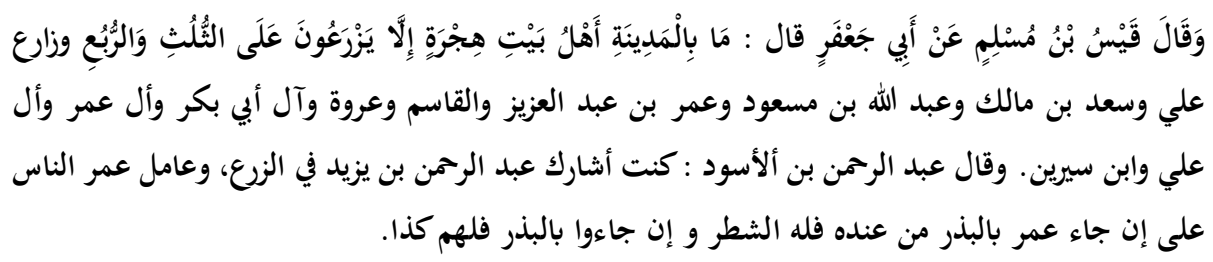

Dan berkata Qais Bin Muslim dari Abi Ja'far (Ia) berkata : Tidaklah Ablul Bit yang berbijrah ke Madianah kecuali mereka bertani (mendapat bagian) sepertiga atau seperempat. Ali dan Sa'ad Bin Malik dan Abdullah Bin Mas'ud dan Umar Bin Abdul Aziz dan Qasim dan 'Urwah dan Keluarga Abu Bakar dan Keluarga Umar dan Keluarga Ali dan Ibnu Sirin. Abdurrabman Bin Al-Aswad berkata : Aku bekerjasama pertanian dengan Abdurrabman Bin Yazid. Umar mempekerjakan orang untuk dia berikan bagian setengah dari hasilnya. Dan ada juga yang berikan semuanya. ${ }^{36}$

Dengan bekerjasama dalam bidang pertanian maka didapatkan solusi mengatasi kerawanan pangan bagi kaum Muhajirin, yang tidak memiliki apa-apa. dan mereka tetap merasa terhormat (memiliki 'Izzah) karena tidak

${ }^{36}$ Al-Imam al-Hafidz Ahmad Bin Ali Bin Hajar al-'Asqallany (773-852 H), FATHU AL-BARY BI SYARHI SHAHIHI AL-BUKHARY, Daar al-Hadits, (al-Qahirah : 2004 M/ 1424 H), Zuzu ke 5, h.13. 
bergantung pada pemberian dan shadaqah kaum Anshar. Sangatlah tepat program yang dibuat orlh Rasulullah shallallabu 'alaibi wa sallam untuk mengatasi persoalan masyarakat Madinah dalam ketahan sosial, ketahanan pangan. Setelah bersaudara merekapun saling bekerjasama, bahu membahu dalam penghidupan dan perekonomian mereka.

Mendirikan Pasar. Pemberdayaan ekonomi lainnya yaitu mendirikan pasar dan mendorong kaum muslimin untuk berniaga. Diceritakan bahwa kaum muhajirin meskipun ditawarkan harta dan kebun oleh kaum Anshar tetapi mereka enggan menerimanya. Mereka hanya minta ditunjukkan pasar seperti shahabat Abdurrahman bin 'Auf yang enggan menerima peberian suadaranya yaitu Sa'id Bin Rabi'ah.

Dan Kaum Muhajirin yang lain pun demikian juga. Ketika orang Anshar menawarkan harta, mereka tidak mau menerimanya meskipun mereka sangant membutuhkan, tapi kaum Muahajirin hanya minta kepada orang Anshar bilamana mereka memanen buah kurma mereka meminta agar mereka yang bekerja memanennya. Selanjut baru mereka mau menerima upah dari saudaranya itu. ${ }^{37}$

\section{KESIMPULAN}

Da'wah kepada ummat manusia, tidak sekedar sebagai seruan untuk melakukan amar ma'ruf dan nahi munkar saja dan tidak sekedar mengurusi hal-hal peribadahan yang bersifat mahdhah dan mengurusi hubungan vertikal kepada Yang Maha Kuasa, tetapi da'wah harus bisa menghadirkan kehidupan ummat manusia yang baik, lebih berkembang dan lebih maju dalam hal ekonomi, sosial politik, budaya dan kebutuhan dasar manusi lainnya.

Pengembangan masyarakat adalah upaya bersama untuk meningkatkan tarap hidup masyarakat menjadi lebih baik. Sejalan dengan tujuan da'wah yang pada intinya juga melakukan perubahan pada pribadi, keluarga dan masyarakat menjadi lebih baik pada semua dimensi kehidupan. Jadi bisa dikatakan pekerjaan pengembangan masyarakat adalah bagian dari pekerjaan da'wah.

${ }^{37}$ Mubarak Furi, AR-RAHIQ AL-Makhtum, 
Konsep-konsep pengembangan masyarakat, baik pendidikan, pemberdayaan ekonomi, peningkatan kesehatan, perbaikan akhlak (etitute) social budaya dan kemajuan teknologi yang bertujuan meningkatkan mutu kehidupan masyarakat merupakan konsep-konsep da'wah.

Langkah-langkah pengembangan masyarakat sepeti ; penentuan obyek pengembangan, penelitian masyarakat, merumuskan target capaian pengembangan, obedukasi masyarakat, identifikasi sumber daya alam dan sumber daya manusia, penentuan strategi dan monitoring merupakan langkah-langkah da'wah berbasis penelitian.

Pembangunan masyarakat Madinah oleh Rasulullah shallallabu'alaibi wa sallam oleh Rasulullah juga melalui tahapan-tahapan ;

Pertama penentuan daerah yang akan dikembangkan ditentukan oleh Allah Subhanbu wa ta'ala lansung. Bahkan beberapa kali petunjuk tentang daerah yang akan menjadi tempat hijrah (daerah yang akan dikembangkan).

Kedua penelitian tentang sumber daya alam dan sumber daya manusianya juga sudah mendapatkan petunjuk dari Allah Subabanabu wa ta'ala, dan juga melalui penelitian terstruktur. Yaitu berdasarkan laporan utusan beliau yang bernama Mush'ab Bin Umair dan interaksi langsung dengan orang Yatsrib yang menyatakan siap dimendukung da'wah (pengembangan masyarakat).

Keempat adanya dukungan kebijakan pemimpin yang dalam hal ini justru Rasulullah shallallabu 'alaibi wasallam langsung sebagai pemimpin. Ini sangat penting bagi pengemnagan masyarakat. Sehingga kebijakan apapun yang akan diambil dilapangan tidak akan mengalami benturan (kendala).

Kelima pembangunan masjid yang merupakan menifestasi hubungan vertical dan horizontal dan juga sebagai solusi problem kemanusiaan yaitu perumahan bagi kaum tuna wisma (ahlu as-suffah)

Keenam program persaudaraan iman (didasari keyakinan yang sama) dan persaudaraan kewilayahan. Yang didasari kesatuan wilayah. Kesatuan State demi kepentingan keamanan bersama.

Ketujuh pemberdayaan ekonomi dengan terobosan kerjasama pertanian.

Kedelapan pemberdayaan ekonomi dengan mendorong perdagangan. 
Kesembilan menghadirkan kepastian hokum yang adil

Beberapa temuan yang belum sempat ditulis di sini antara lain :

Kesepulub pembentukan pasukan keamanan dan pertahanan wilayah.

Kesebelas ekspansi wilayah kekuasan yang didasari tujuan menebar keadilan dan ketaatan beragama.

Dari uraian teori-teori di atas, kita dapat mengatakan bahwa konsep pengembangan masyarakat menurut Islam lebih holistik dari pada konsep pengembangan masyarakat secara umum. Dalam konsep pengembangan masyarakat menurut Islam tidak hanya dibangun hubungannya dengan sesama manusia (hubungan vertikal) tetapi dibangun juga hubungannya dengan sang pencipta Allah Yang Maha Kuasa (horisontal).

Konsep Pengembangan Masyarakat adalah bagian dari Konsep Da'wah. Oleh kerena itu hendaknya para pelaku pengembangan masyarakat dari kalangan umum menggunakan konsep Da'wah sebagai konsep pengembangan masyarakat. Dan yang lebih terpenting lagi sudah seharusnya bagi para da'i, melakukan pengembangan masyarakat sebagai implementasi konsep da'wah.

\section{DAFTAR PUSTAKA}

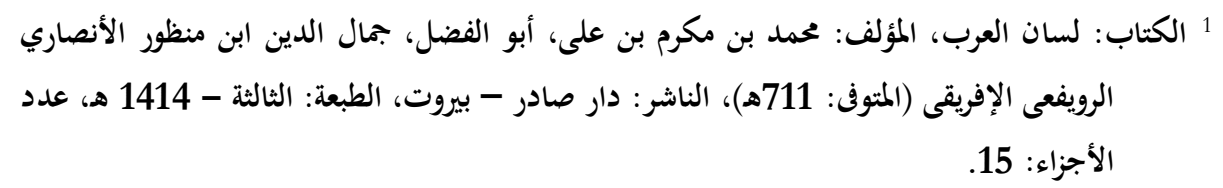

Al-Anshary, Abdul Quddus, ATSAR AL-MADINAH, Maktabah Salafiyyah, (Madinah Al-Munawwarah : 1973 M/ 1393 H), Cet. Ke5

Al-Imam al-Hafidz Ahmad Bin Ali Bin Hajar al-'Asqallany $(773-852 \mathrm{H})$, FATHU AL-BARY BI SYARHI SHAHIHI AL-BUKHARY, Daar al-Hadits, (al-Qahirah : 2004 M/ 1424 H), Zuzu ke 5. 


\section{$A L-Q U R^{\prime} A N$}

As-Samhudy, Nuruddin Ali Bin Abdullah as-Samhudy (911 h), WAFA AL-WAFA LI AKHBARI ALMUSHTHAFA, (Makkah dan Madinah : $2001 \mathrm{M} / 1422 \mathrm{H})$ : Muassasah al-Furqan li at-turats alislamiyyah, Cet. Ke-1 jilid 1.

\section{HADITS SHAHIH MUSLIM}

\section{HADITS SHAIH BUKHARY}

Ibnu Hisyam, Abdul Malik Bin Hisyam Bin Ayyub Al-Humairy al-Ma'afiriAbu Muhammad Jamaluddin $(213 \mathrm{H}), \operatorname{SIR} A H \mathrm{~N} A B A W Y Y A H L I$ IBNI HISYAM, ( Mesir : 1955M/1375H), Syirkati Maktabah wa Mathba'ah Musthafa al-Banyal-Halaby wa Auladihi, Jilid 1.

Imam Syihabuddin Abi Abdillah Yaqut Bin Abdillah al-Hamwi ar-Rumy al-Baghdady $(626 \mathrm{H}), M U^{\prime} J A M A L-B U L D A N$, Dar al-Kutub al'Ilmiyyah, (Bairut-libanon : ...), Juz ke-5.

Jamaluddin Muhammad Bin Mukrim Ibnu al-Manzhur Al-Afriqy AlMishry (630-711 H), Lisan al-'Arab, Dar as-Shadir, Bairut, Lubnan : .... ) , Juzu ke-5.

Mudzakkir, M. Djauzi, TEORI DAN PRAKTEK PENGEMBANGAN MASYARAKAT, Usaha Nasional, (Surabaya : 1986).

Muhammad Bin Hasan Bin Zabalah (199H), AKHBAR AL-MADIN AH, Markaz Buhuts wa Dirasat, (Madinah al-Munawwarah : 2003 M/ 1424).

Muhammad Bin Jarir, Bin Yazid Bin Katsir, Bin Ghalib Al-'Amily, Abu Jafar At-Thabary $(310 \mathrm{H}), J A M I^{\prime} A L-B A Y A N$ FI TAFSIR ALQUR'AN, Muasasah Ar-Risalah : $2000 \mathrm{M} / 1420 \mathrm{H}$

Munawwir, Ahmad Warson, KAMUS AL-MUNAWWIR, Pustaka Progressif (Surabaya : 1997), Cet: ke-4.

Nasdian, Fredian Tonny, PENGEMBANGAN MASYARAKAT, Yayasan Pustaka Obor Indonesia, (Jakarta : 2014).

Nuruddin Ali Bin Abdullah As-Samhudi (911 H), WAFA AL-WAFABI AKHBARI DAR AL-MUSHTHAAFA, Makkah-Madinah AlMunawwarah : Muassah al-Furqan Lit Turas al-Isllamy. 
Sayyaid Abdul-'Aziz, Tarikh al-arab, h.333. al-Jabali, Tarik al-'Arab fi alJabily, h 187. Al-Khatrawi, Al-Madinah fi ashri al-Jahily, h. 24.

Shafiyyurrahman Al-Mubarakfury, AR-RAHIQI AL-MAKHTUM, SIRAH NABAWIYYAH, Pustaka Al-Kautsar (Jakrta : 1997).

Tim penyusunan kamus, PUSAT PEDANMBINAAN DAN PENGEMBANGAN BAHASA, KAMUS BESAR BAHASA INDONESLA (Jakarta: Balai Pustaka, 1994) ed. 2, cet. 3.

Wildan Saugi, Sumarno, SMPIT As-Salaam Fakfak Papua Barat, Universitas Negeri Yogyakarta, wildan_saugi@yahoo.com, sumarno_unj@yahoo.uk, PEMBERDAYAAN PEREMPUAN MELALUI PELATIHAN PENGOLAHAN BAHAN PANGAN LOKAL. Jurnal Pendidikan dan Pemberdayaan Masyarakat Volume 2 - Nomor 2, November 2015, (226 - 238) Available online at JPPM Website: http://journal.uny.ac.id/index.php/jppm Copyright (C) 2015, JPPM, Print ISSN: 2355-1615, Online ISSN: 2477-2992 Wildan Saugi, Sumarno, SMPIT As-Salaam Fakfak Papua Barat, Universitas Negeri Yogyakarta, wildan_saugi@yahoo.com, sumarno_unj@yahoo.uk

Yasin Ghadhban, MADINATU YATSRIB QABL AL-ISLAM. Daar alBasyir, (Aman - Urdun : 1993), Cet. Pertama. 